\title{
Correction to: Twenty years of the Journal of Educational Change: A Perspective from the Global South
}

\section{Brahm Fleisch $^{1}$}

Published online: 31 July 2020

(c) Springer Nature B.V. 2020

\section{Correction to: Journal of Educational Change https://doi.org/10.1007/s10833-020-09373-4}

The article title in the original publication contains an error. The correct title is presented in this Erratum, as the journal existed 20 years when this article was published and not 25 years.

Publisher's Note Springer Nature remains neutral with regard to jurisdictional claims in published maps and institutional affiliations.

The original article can be found online at https://doi.org/10.1007/s10833-020-09373-4.

Brahm Fleisch

Brahm.Fleisch@wits.ac.za

1 University of Witwatersrand, Johannesburg, South Africa 